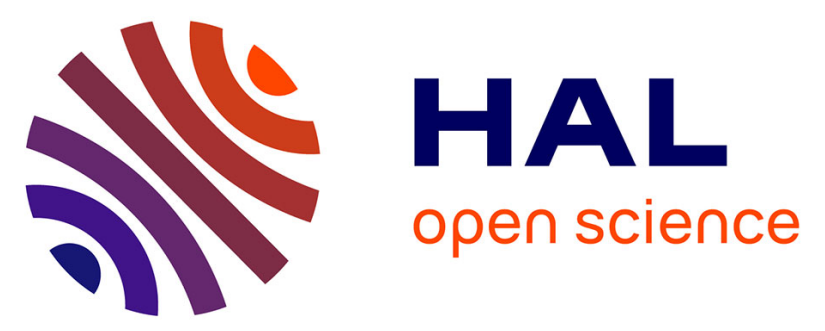

\title{
Evaluation of double formalin-Lugol's fixation in assessing number and biomass of ciliates: an example of estimations at mesoscale in NE Atlantic
}

Hera Karayanni, Urania Christaki, France van Wambeke, Dalby Andrew

\section{- To cite this version:}

Hera Karayanni, Urania Christaki, France van Wambeke, Dalby Andrew. Evaluation of double formalin-Lugol's fixation in assessing number and biomass of ciliates: an example of estimations at mesoscale in NE Atlantic. Journal of Microbiological Methods, 2004, 56 (3), pp.349 - 358. 10.1016/j.mimet.2003.11.002 . hal-01780291

\section{HAL Id: hal-01780291 \\ https://hal.science/hal-01780291}

Submitted on 15 Jun 2018

HAL is a multi-disciplinary open access archive for the deposit and dissemination of scientific research documents, whether they are published or not. The documents may come from teaching and research institutions in France or abroad, or from public or private research centers.
L'archive ouverte pluridisciplinaire HAL, est destinée au dépôt et à la diffusion de documents scientifiques de niveau recherche, publiés ou non, émanant des établissements d'enseignement et de recherche français ou étrangers, des laboratoires publics ou privés. 


\title{
Evaluation of double formalin-Lugol's fixation in assessing number and biomass of ciliates: an example of estimations at mesoscale in NE Atlantic
}

\author{
Hera Karayanni $^{\mathrm{a}, \mathrm{b}}$, Urania Christaki ${ }^{\mathrm{b}, \mathrm{c}, *}$, France Van Wambeke ${ }^{\mathrm{a}}$, Andrew P. Dalby ${ }^{\mathrm{b}}$ \\ ${ }^{a}$ Microbiologie Marine, CNRS, UMR 6117, Campus de Luminy, case 907, 13288 Marseille cedex 9, France \\ ${ }^{\mathrm{b}}$ Hellenic Centre for Marine Research, P.O. Box 712, 19013, Anavissos, Greece \\ ${ }^{\mathrm{c}}$ Université du Littoral Côte d'Opale, MREN, 32 Avenue Foch, 62930 Wimereux, France
}

Received 7 August 2003; received in revised form 3 November 2003; accepted 4 November 2003

\begin{abstract}
Ciliated protozoa are potential grazers of primary and bacterial production and act as intermediaries between picoplankton and copepods and other large suspension feeders. Accurate determination of ciliate abundance and feeding mode is crucial in oceanic carbon budget estimations. However, the impact of different fixatives on the abundance and cell volume of ciliates has been investigated in only a few studies using either laboratory cultures or natural populations. Lugol's solution and formalin are the most commonly used fixatives for the preservation of ciliates samples. In the present study, the aim was to compare $0.4 \%$ Lugol's solution and $2 \%$ borated-formalin fixation and evaluate the need of counting duplicate samples each using a different fixative. For this, a large number of samples $(n=110)$ from the NE Atlantic was analyzed in the frame of POMME program (Multidisciplinary Mesoscale Ocean Program). We established a statistically significant relationship $(p<0.0001)$ between Lugol's and formalin fixed samples for both abundance $\left(r^{2}=0.50\right)$ and biomass $\left(r^{2}=0.76\right)$ of aloricate ciliates which showed that counts were higher in Lugol's solution by a factor of 2 and a non-taxon specific cell-loss in formalin. However, loricate ciliate abundance in our samples which were represented primarily by Tintinnus spp. did not show any difference between the two treatments. Abundance and biomass of mixotrophic ciliates (chloroplast-bearing cells) were for various reasons underestimated in both treatments. Our results show that unique fixation by formalin may severely underestimate ciliates abundance and biomass although their population may not alter. For this reason, Lugol's solution is best for the estimation of their abundance and biomass. However, for counts of mixotrophs and the evaluation of the ecological role of ciliates in carbon flux, double fixation is essential. Compromises regarding the fixatives have lead to severe underestimations of mixotrophs in studies conducted by now.
\end{abstract}

(C) 2003 Elsevier B.V. All rights reserved.

Keywords: Double formalin; Lugol's fixation; Ciliates

\section{Introduction}

* Corresponding author. Université du Littoral Côte d'Opale, MREN, 32 Avenue Foch, 62930 Wimereux, France.

E-mail address: Christaki@mren2.univ-littoral.fr (U. Christaki).
Ciliated protozoa, aloricate oligotrichous taxa and loricate choreotrichs (tintinnids), are the most abundant microzooplanktonic organisms in the 20-200- 
$\mu \mathrm{m}$ size range (Dussart, 1965). They are ubiquitous in marine waters where they feed on picoplankton (Sherr et al., 1986; Bernard and Rassoulzadegan, 1993; Christaki et al., 1999), nanoplankton (Pilling et al., 1992), or on other constituents of the microplankton (Bernard and Rassoulzadegan, 1990). The only pathway through which small primary producers can enter into the food web and reach higher trophic levels is from grazing by protozoa (flagellates and ciliates), which are potential food-web intermediaries that repackage picoplankton production in a form available to copepods and other large suspension feeders (Levinsen and Nielsen, 2002). There are several mixotrophic taxa among ciliates which can sequester photosynthetically functional chloroplasts from a variety of chromophytic and chlorophytic algae (Jonsson, 1987; Stoecker et al., 1987). These can contribute up to the half the biomass of oligotrichs (Stoecker et al., 1987; Pitta and Giannakourou, 2000) and up to $20 \%$ of microplanktonic primary production in some coastal waters (Stoecker, 1991).

Ciliates are therefore very important organisms for our understanding of food-web dynamics and as such, require accurate quantification of abundance and feeding mode in order to generate useful carbon budget estimations, among other data. Preferentially, living material in combination with specific equipment would be required for accurate determination of cell volume (Putt and Stoecker, 1989), quantification (Sime-Ngando et al., 1990; Lynn and Montagnes, 1991) and identification of various species of ciliates (Maeda and Carey, 1985; Sime-Ngando et al., 1990; Montagnes and Lynn, 1991). Unfortunately, this is not always feasible as analysis is time-consuming requiring long-term sample storage. A compromise is to use a fixative to preserve the samples in situ. However, there are challenges associated with this.

The two fixatives traditionally used for this purpose are Lugol's solution and formalin (Burkill et al., 1993; Stoecker et al., 1994b). Their effect on the determination of ciliate abundance and cell volume has been investigated in only a few studies using either laboratory cultures (Putt and Stoecker, 1989; Ohman and Snyder, 1991) or natural populations (Sime-Ngando et al., 1990; Leaky et al., 1994). Current observations of the effects of both fixatives used on ciliates are summarized below.
For abundance estimates, Lugol's seems to be the most effective fixative (Revelante and Gilmartin, 1983; Stoecker et al., 1989; Leaky et al., 1994) and cell loss may be minimal compared to live counting (Sime-Ngando et al., 1990). Low concentrations of Lugol's solution have traditionally been used to preserve microplankton samples (Sherr and Sherr, 1993), however, the effectiveness of Lugol's for long-term storage of samples is unclear. Cell loss may increase with storage time (Sime-Ngando and Groliere, 1991), however, this does not appear in cell loss experiments conducted by Ohman and Snyder (1991). Comparison of cell volumes of live and fixed cells has shown that relative to Lugol's, formalin is more likely to minimize shrinkage of ciliates (Putt and Stoecker, 1989; Choi and Stoecker, 1989; Ohman and Snyder, 1991). Another disadvantage of Lugol's solution is that it masks chlorophyll fluorescence of mixotrophic forms and fluorescence of natural or labeled ingested prey, used as feeding indicators in grazing experiments. Hence, to obtain estimates of the trophic status of ciliates (autotrophs, mixotrophs and heterotrophs), samples are fixed with borated-formalin solution (final concentration $2 \%$ ). However, various studies have shown that although formalin allows observing chlorophyll fluorescence, it can cause severe loss of cells (Revelante and Gilmartin, 1983; Stoecker et al., 1989, 1994a). It is thus evident that no single fixation method is ideal for all purposes. Notwithstanding, since ciliate counting is quite time consuming and sample storage problematic, it is difficult to analyze duplicates with both formalin and Lugol's fixation and different compromises regarding the fixatives are necessary (e.g. Dolan and Marrasé, 1995; Pitta et al., 2001).

In order to compare Lugol's and formalin fixation, duplicate samples from the same water sample were examined each using a different fixative. We needed to establish a quantitative relationship between formalin and Lugol's counts, therefore, a large number of samples (110 in total) from different stations, depths and seasons in an oceanic area (NE Atlantic) were analyzed. We evaluated in particular the accuracy of mixotrophic ciliate numbers from both fixation techniques (duplicate counting). Additionally, we compared the two fixatives in terms of full (containing cell) versus empty tintinnid loricas. 


\section{Materials and methods}

Sampling was conducted in the NE Atlantic Ocean $\left(16-22^{\circ} \mathrm{W}, 38-45^{\circ} \mathrm{N}\right)$ within the framework of POMME (Multidisciplinary Mesoscale Ocean Program). The study covered an area of $500 \mathrm{~km}$ (eastwest) by $750 \mathrm{~km}$ (north-south) centred on $41.5^{\circ} \mathrm{N}$, $19^{\circ} \mathrm{W}\left(16 \mathrm{~W}-22^{\circ} \mathrm{W} / 38 \mathrm{~N}-45^{\circ} \mathrm{N}\right)$ (Fig. 1). For ciliate enumeration, $500 \mathrm{ml}$ samples were taken from the upper $100 \mathrm{~m}$ at different increments $(5,10,20,30,40$, $50,60,80,100 \mathrm{~m}$ ) during the winter (FebruaryMarch), spring (April-May) and fall (late AugustOctober). Data for fixative comparison were gathered from 110 samples corresponding to 48 study sites (10, 17 and 21 sites for winter, spring and fall sampling, respectively). The $500-\mathrm{ml}$ samples were each gently mixed and then 250-ml sub-samples (duplicates) were decanted into two opaque glass bottles. One duplicate was fixed with borax-buffered $37 \%$ formaldehyde (borax purity: $99.8 \%$, formaldehyde purity: $37-38 \%$, stabilized with $10 \%$ methanol) solution filtered on $0.2-$ $\mu \mathrm{m}$ cellulose filters and the other with acid Lugol's solution in order to obtain final concentrations of $2 \%$ and $0.4 \%$, respectively. Fixative solutions were diluted with Millipore Milli-Q purified water (deionized; decarbonized TOC $<15 \mathrm{ppb}$ ). One litre of acid Lugol's solution contained: $50 \mathrm{~g}$ iodine (I); $100 \mathrm{~g}$ potassium iodide (KI); $100 \mathrm{ml}$ acetic acid $\left(\mathrm{CH}_{3} \mathrm{COOH}\right)$; and Milli-Q purified water. The samples were always added to the fixative so that the preserved ciliates experienced at least the minimum target fixative concentration at all times (Gifford and Caron, 2000). The treatment bottles were gently inverted once in order to ensure proper mixing of the fixative. The samples were then stored at $4{ }^{\circ} \mathrm{C}$ in the dark until analysis (1-6 months).

In the laboratory, samples were left to settle for 34 days at $4{ }^{\circ} \mathrm{C}$. Before examination, the top $150 \mathrm{ml}$ of the sample was gently siphoned off using a low vacuum pump. The bottom $100 \mathrm{ml}$ of the sample was transferred into Hydro-Bios Kiel combined plate settling chambers (model no. 435 025), allowing it to settle for a minimum of $16 \mathrm{~h}$ and then examined with an Olympus IX-70 inverted microscope at $400 \times$. The

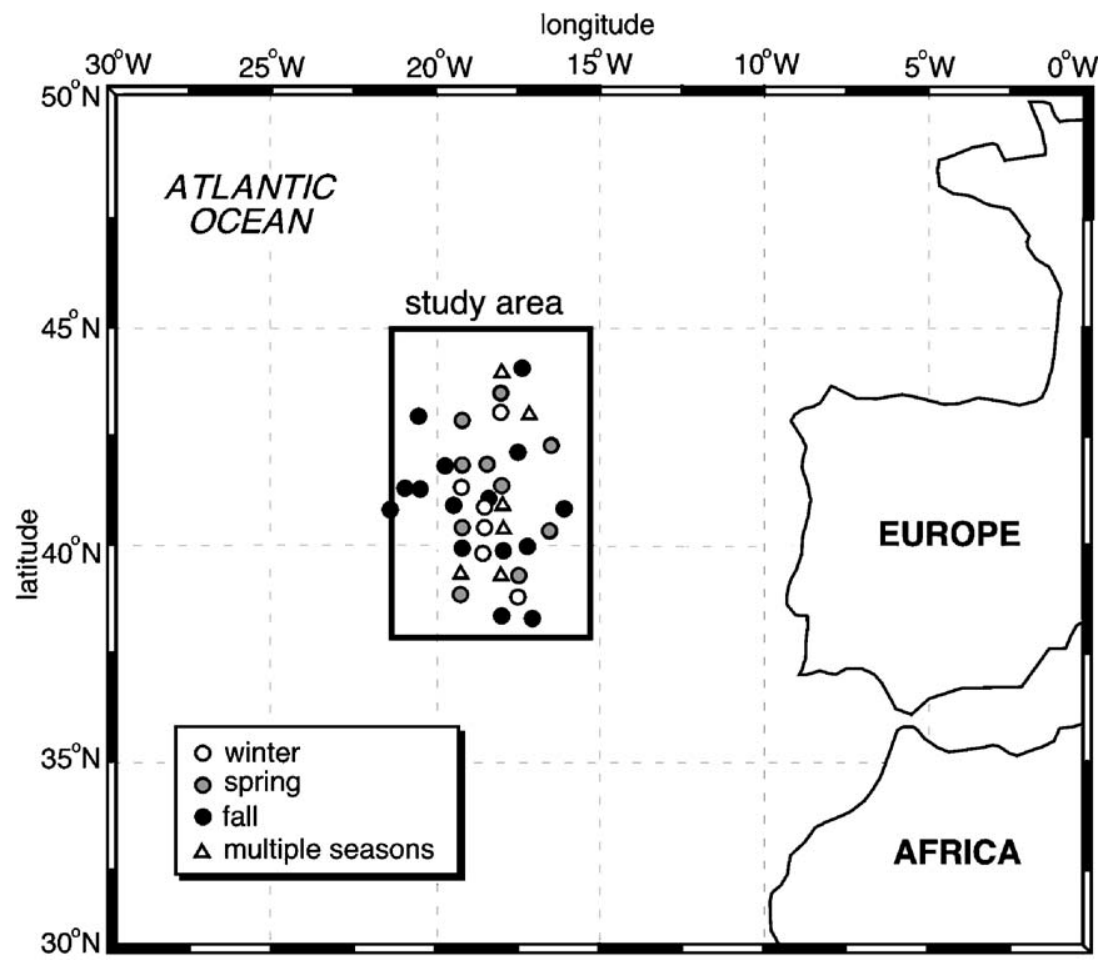

Fig. 1. Sampling sites for fixatives comparison during POMME cruises, winter to fall 2001. 
microscope was equipped for transmitted light, phase contrast and epifluorescence microscopy. Blue light excitation (DM 500-nm dichroic mirror, BP 450 to 480-nm exciter filter, BA 515-nm barrier filter and a 100 -W mercury burner) was used to detect chlorophyll autofluorescence and to distinguish plastidic from non-plastidic ciliates. Lugol's fixed samples were examined with phase contrast while boratedformalin fixed samples were enumerated using epifluorescence microscopy. In order to compare Lugol's with formalin counts for mixotrophic ciliates, mixotrophic oligotrich species with very distinctive gross morphologies (Laval-Peuto and Rassoulzadegan, 1988), Laboea sp. and Tontonia spp. were counted in Lugol's fixed samples as well. On several occasions, the settling efficiency at each stage of the settling process (opaque bottles and settling chambers) was examined by resettling the supernatant solution and then examining it microscopically for the presence of ciliates, however, examination of the supernatant solution did not show any cell loss.

All ciliates in each sample were enumerated and assigned to one of the following groups: oligotrichs and tintinnids. The former is comprised of aloricate (naked) taxa of Oligotrichida and Choreotrichida and the latter loricate species (order Choreotrichida, suborder Tintinnina, Montagnes and Lynn, 1991). Oligotrich ciliates were grouped into four taxa (Table 1) on the basis of shape, size, visible ciliature and morphology and identified wherever possible to the species level based on the works of Maeda and Carey (1985) and Maeda (1986). Furthermore, Strombidium spp. was separated into three morphological types (morphotypes): conical, spherical and prolate-spheroid. In addition, oligotrich ciliates were separated into four cell-volume categories from $<10^{3}$ to $>10^{5} \mu \mathrm{m}^{3}$ (Montagnes et al., 1988; Leaky et al., 1992). Tintinnids were identified based on the lorica shape and dimensions by reference to Jörgensen (1924) and Kofoid and Campbell (1929). Empty loricas were counted separately.

Biovolumes of all oligotrich taxa and morphotypes identified in this study (Table 1) were calculated using the linear dimensions of all cells present in 22 randomly selected samples for each treatment. Linear dimensions (length and diameter) were measured at $400 \times$ using a calibrated ocular micrometer on the microscope. Equations for a sphere, prolate spheroid
Table 1

$Z$ adjusted-Values (Mann-Whitney rank-sum test) resulted from the comparison of cell-volumes of different morphotypes and size classes identified in formalin and Lugol's fixed samples

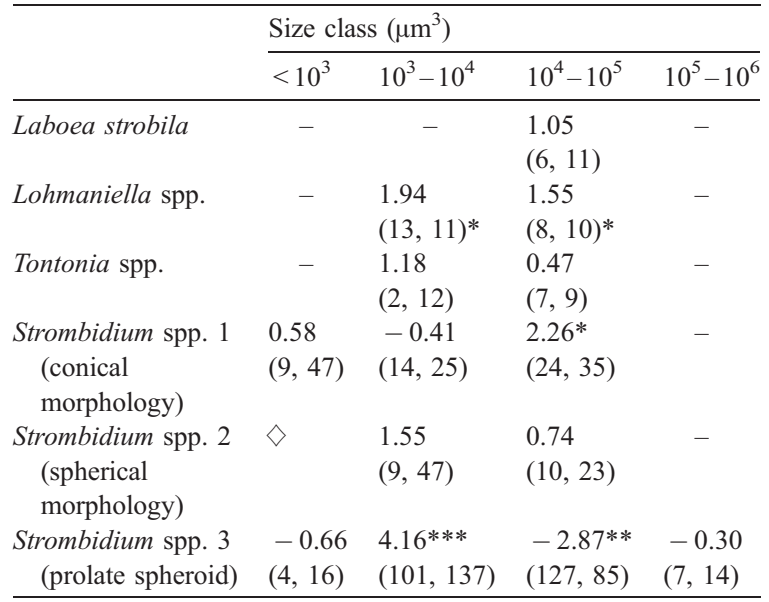

In parentheses: (valid $N$ in formalin, valid $N$ in Lugol's).

$\diamond:$ No data for formalin.

$* p<0.05$.

$* * p<0.01$.

$* * * p<0.001$.

or cone were applied depending on cell shape. Oral membranelles and tail structures were not included in the estimation of cell geometry (Stoecker et al., 1994a). Biovolumes were converted to biomass using volume-to-carbon conversion factors 0.19 and $0.14 \mathrm{pg}$ $\mathrm{C} \mu \mathrm{m}^{-3}$ for Lugol's and formalin preserved samples, respectively (Putt and Stoecker, 1989).

To test for significant differences between abundance or biomass in Lugol's and borated-formalin samples, the paired $t$-test was used. To determine whether the mean cell volumes of different taxa differ between the two treatments, the Mann-Whitney test was used as the data sets for most taxa studied were small. In both cases, the hypothesis tested was that there was no difference between the means or the medians of the two populations. Statistical analysis was carried out with Statgraphics plus 4.0. and Statistica.

\section{Results}

Aloricate ciliates of the family Strombidiidae (Strombidium spp., Laboea sp. and Tontonia spp.) 

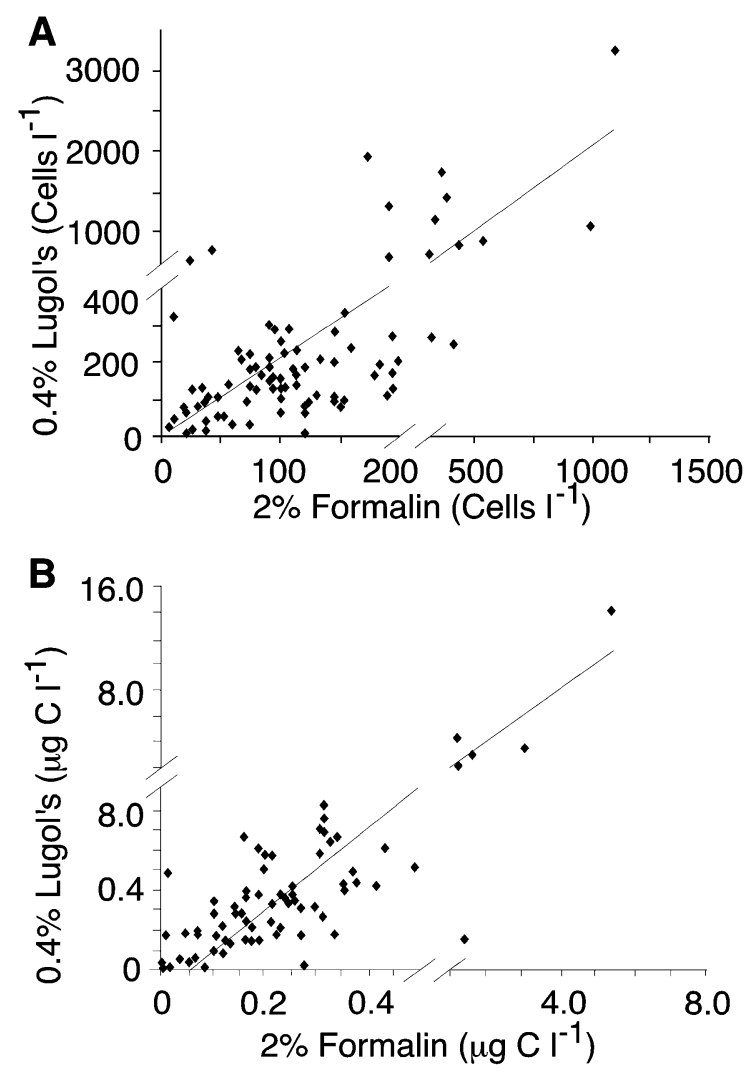

Fig. 2. Oligotrich ciliates abundance (A) and biomass (B) in Lugol's fixed samples plotted against abundance and biomass in formalin, respectively. Fitted regression lines: (A) $y=8.16439+2.0624 x$, $r^{2}=0.50, p<0.0001 \quad(n=110)$ and (B) $y=-0.11771+2.06584 x$, $r^{2}=0.76, p<0.0001(n=110)$.

dominated the ciliate community in numbers and biomass year round. Additionally, one taxon of Strobilidiidae, Lohmaniella spp., was identified in several samples, but it never became dominant. Loricate ciliates of Tintinnus spp. were dominant on two occasions $\left(41.5^{\circ} \mathrm{N}, 18^{\circ} \mathrm{W}\right.$ and $43.2^{\circ} \mathrm{N}$, $18.5^{\circ} \mathrm{W}$ ) during the spring. In 80 out of 110 duplicate samples counted, abundance and biomass of oligotrichs were higher in the Lugol's fixed samples ( $72 \%$ of samples). Abundance of oligotrichs in the $2 \%$ borated-formalin fixed samples ranged between 6 and 1091 cells $1^{-1}$, while in $0.4 \%$ acid Lugol's fixed samples, the range was $8-3252$ cells $1^{-1}$. Their,

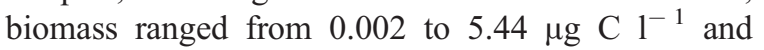
from 0.01 to $14.09 \mu \mathrm{g} \mathrm{C} 1^{-1}$ for formalin and Lugol's samples, respectively.
The paired $t$-test comparison showed that both abundance and biomass of oligotrichs were significantly different in Lugol's and formalin fixed samples $(p<0.0001, n=110)$. A statistically significant linear relationship was calculated between Lugol's and formalin fixed samples for both cell abundance and biomass $\left(r^{2}=0.5\right.$ and 0.76 , respectively, $p<0.0001$, Fig. 2A,B) showing that abundance and biomass in Lugol's fixed samples were about $100 \%$ higher than in formalin (slope of the regression line $=2$, Fig. 2A,B).

Biovolumes were calculated using linear dimensions of all cells identified in Lugol's and formalintreated samples. Furthermore, cells of each taxon and morphotype were separated in 4 cell-volume categories: $<10^{3}, 10^{3}-10^{4}, 10^{4}-10^{5}$ and $10^{5}-10^{6}{\mu \mathrm{m}^{3}}^{3}$. Mean cell volumes in Lugol's samples ranged between $75 \%$ and $119 \%$ of formalin fixed samples. In 4 out of 14 cases, no difference was observed between formalin and Lugol's fixed samples, while in 2 cases, cell-volume in Lugol's was greater than in formalin. Statistically significant differences between cell-volumes were observed only for one to two size classes of Lohmaniella spp., Strombidium spp. 1 and Strombidium spp. 3 (Table 1).

Mixotrophic oligotrichs belonged to the following taxa: Strombidium spp., Laboea strobila and Tontonia spp. Laboea strobila and Tontonia spp., can be distinguished in Lugol's samples because of their characteristic morphology. Thus, based only on $L$. strobila and Tontonia spp. counts, mixotrophic abundance in Lugol's ranged from 0 to 75 cells $1^{-1}$, while

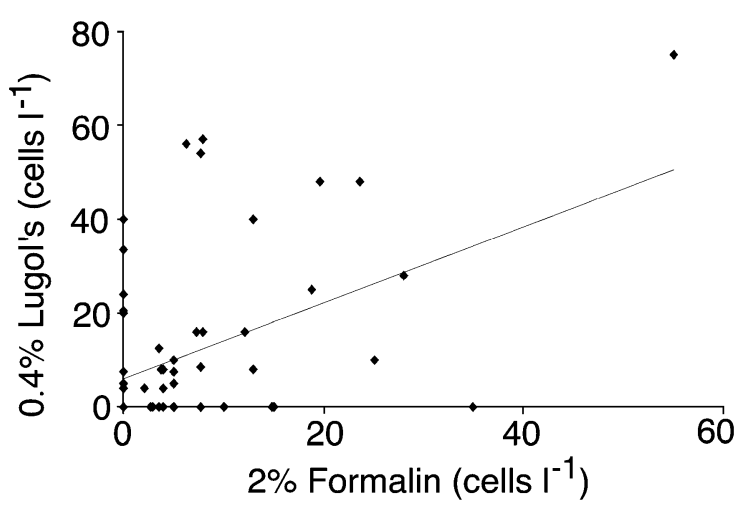

Fig. 3. L. strobila and Tontonia spp. abundance in Lugol's solution plotted against abundance in formalin $(n=61)$. 
their abundance in formalin ranged from 0 to 55 cells $1^{-1}$. Lugol's mean counts were higher than for formalin by a factor of $>2$, however, no relationship could be established between Lugol's and formalin abundances; this is likely due to the small number of cells present in the $250 \mathrm{ml}$ samples (from 0 to $<20$ cells, see Fig. 3) which was not statistically useful. Thus, in 34 out of a total of 61 samples, L. strobila and Tontonia spp. were found in either Lugol's or formalin but not in both fixatives (Fig. 3). Furthermore, total mixotrophic abundance ranged from 0 to 302 cells $1^{-1}$ in formalin fixed samples where chlorophyll fluorescence of Strombidium spp. could be also distinguished. Thus, the $p$-value of the paired $t$ test showed that there is a statistically significant difference of ciliate abundance in formalin compared to Lugol's fixation ( $p<0.0001, n=92)$. Conversion of numbers of mixotrophs - L. strobila and Tontonia spp. in Lugol's and L. strobila, Tontonia spp. and Strombidium spp. in formalin fixed samples-into biomass, resulted in similar values in the two kinds of treatments and ranged from 0 to $\sim 1.2 \mu \mathrm{g} 1^{-1}$. It is clear that total mixotroph abundance and biomass were severely underestimated in both treatments for different reasons: in formalin because of severe cell loss and in Lugol's because of chlorophyll masking.

Tintinnus spp. was abundant during the spring cruise. The total lorica abundance present in the samples ranged from 20 to 1076 and from 0 to 992 cells $1^{-1}$ in formalin and Lugol's samples, respectively. On average, $60 \%$ of the loricas were full in both

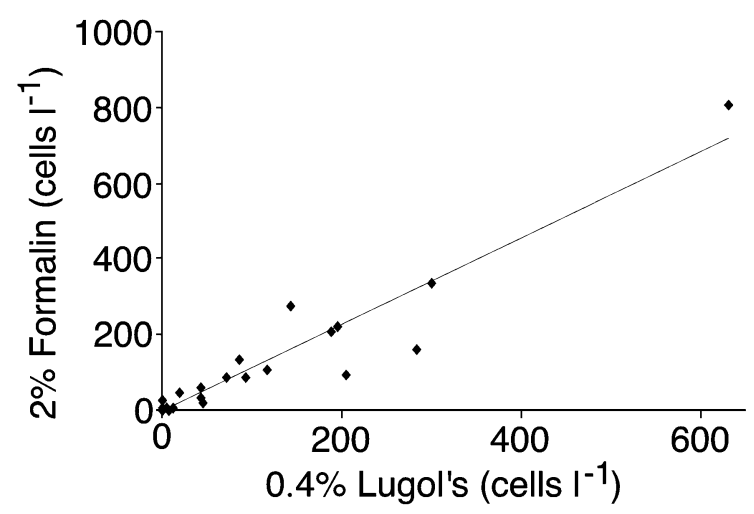

Fig. 4. Tintinnus spp. (full loricas) abundance in Lugol's solution plotted against abundance in formalin $r^{2}=0.896, p<0.0001$ $(n=24)$. treatments. The abundance of full loricas was similar in Lugol's and formalin (Fig. 4) and the paired $t$-test did not show any statistically significant difference between the two treatments $(p>0.05, n=24)$.

\section{Discussion}

The taxonomic composition of the ciliate community sampled from the NE Atlantic study area was dominated by members of the family Strombidiidae (Strombidium spp., L. strobila, Tontonia spp.) as has already been recorded in previous studies conducted in the same area (Burkill et al., 1993; Stoecker et al., 1994b; Quevedo and Anadón, 2001). Additionally, the abundance and biomass were within the ranges previously reported for the northeastern Atlantic Ocean (Burkill et al., 1993; Stoecker et al., 1994b).

Previous studies conducted with marine or freshwater species from natural populations or cultures on a restricted number of samples (1-12, Table 2) reported cell densities for formalin fixed samples from 28 to $\sim 100 \%$ (mean $=70 \pm 22 \%$ ) compared to Lugol's solution fixed samples (Table 2). Based on 110 samples, the present study established a statistically significant relationship of 2:1 for Lugol's and formalin samples (Fig. 2). Replicate counts of samples treated with the same fixative are in the order of $12-$ 17\% (Sime-Ngando et al., 1990; Thouvenot et al., 1999).

Ohman and Snyder (1991) argued that there is no systematic trend between concentration of acid Lugol's solution and cell densities although experiments conducted by Stoecker et al. (1994a) showed significantly higher oligotrich counts in concentrated $(\geq 10 \%)$ rather than in dilute $(\leq 2 \%)$ acid Lugol's solution. A previous study in the north Atlantic (Stoecker et al., 1994a) reported a lower mean difference between 10\% Lugol's and 2\% formalin samples $(36 \%)$ than in our samples $(50 \%)$. Different sampling methodology could be a probable explanation for the discrepancy between our data and that of Stoecker et al. (1994a) in that the latter reported results from a lower number of samples (12 samples, see Table 2) and from only one sampling site and period, whereas our data set was from different sampling sites and periods. Differences in cell loss could be also interpreted as differences in physiological and nutritional 
Table 2

Comparison of Lugol's and formalin fixation on the abundance of aloricate ciliates

\begin{tabular}{|c|c|c|c|c|c|}
\hline Species & System & Fixatives & $\mathrm{F} / \mathrm{L}$ & $N(n)$ & Source \\
\hline Total ciliates & Lake Aydat & $1 \% \mathrm{~L}, 2 \% \mathrm{uF}$ & 76 & $1(3)$ & Sime-Ngando et al. (1990) \\
\hline Strombidium sp. & culture & $2 \% \mathrm{~L}, 1 \% \mathrm{~F}$ & $\begin{array}{l}\sim 100 \text { stationary phase, } \\
\mathrm{L}>\mathrm{F} \text { exponential phase } \\
(\% \text { not given })\end{array}$ & $9-11$ & Ohman and Snyder (1991) \\
\hline Aloricate ciliates & S. Brazilian Coast & $1 \% \mathrm{~L}, 1 \% \mathrm{bF}$ & 91 & 8 & Suzuki et al. (1991) \\
\hline Aloricate ciliates & N. Atlantic culture & $10 \% \mathrm{~L}, 2 \% \mathrm{bF}$ & 64 & 12 & Stoecker et al. (1994a) \\
\hline S. spiralis & & $2 \%, 5 \%, 10 \% \mathrm{~L}$ & $91,99,83$ & (3) & \\
\hline S. capitatum & & $2 \% \mathrm{bF}$ & $85,71,64$ & & \\
\hline Aloricate ciliates & Plymouth Sound & $0.4 \% \mathrm{~L}, 1 \% \mathrm{bF}$ & 52 & $1(3)$ & Leaky et al. (1994) \\
\hline Balanion sp. & culture & $0.4 \% \mathrm{~L}, 1 \% \mathrm{bF}$ & 28 & $1(3)$ & \\
\hline S. epidemum & culture & $0.4 \% \mathrm{~L}, 1 \% \mathrm{bF}$ & 35 & $1(3)$ & \\
\hline Aloricate ciliates & NE Atlantic & $0.4 \% \mathrm{~L}, 2 \% \mathrm{bF}$ & 50 & 110 & This study \\
\hline
\end{tabular}

Ratios expressed as percentages. $N(n)$ : number of samples (replicates per fixative), $\mathrm{L}=$ Lugol's, $\mathrm{F}=$ formalin, $\mathrm{uF} / \mathrm{bF}=\mathrm{unbuffered} / \mathrm{buffered}$ formalin.

states of aloricate ciliates (Ohman and Snyder, 1991; Leaky et al., 1994).

Mean cell volumes were greater in formalin fixed samples compared to Lugol's for most taxa and sizeclasses identified in our samples. Previously reported results showed the same trend between the two fixatives (Table 3). In these studies, cell volume in Lugol's ranged from $42 \%$ to $94 \%$ (mean $69 \pm 14 \%$ ) for formalin-treated cells. In our study, the range was from $78 \%$ to $109 \%$ (mean $89 \pm 11 \%$ ) which corresponds to the higher limits of values previously reported for aloricate ciliates. Previous studies have

Table 3

Comparison of Lugol's solution and formalin fixation on the mean cell volume of ciliated protozoa

\begin{tabular}{|c|c|c|c|c|c|c|}
\hline Species & System & Fixatives & Fixed/Live & $\mathrm{L} / \mathrm{F}$ & $N(n)$ & Source \\
\hline $\begin{array}{l}\text { L. strobila, Strombidium spp., } \\
\text { S. spiralis }\end{array}$ & Culture & $\begin{array}{l}2 \% \mathrm{~L} \\
2 \% \mathrm{bF}\end{array}$ & $\begin{array}{l}78 \\
103\end{array}$ & 76 & $20-50$ & Putt and Stoecker (1989) \\
\hline Strombilidium spiralis & Culture & $\begin{array}{l}\mathrm{L} \\
1 \% \mathrm{~F}\end{array}$ & $\begin{array}{l}64 \\
80\end{array}$ & 80 & $20-30 /$ replicate $(3)$ & Choi and Stoecker (1989) \\
\hline Strombidium acutum & Culture & $\begin{array}{l}2 \% \mathrm{~L} \\
1 \% \mathrm{~F}\end{array}$ & $\begin{array}{l}74 \\
83\end{array}$ & 90 & $20-30 /$ replicate $(3)$ & \\
\hline Strombidium sp. & Culture & $\begin{array}{l}1 \% \mathrm{~L} \\
2 \% \mathrm{~L} \\
1 \% \text { bF or } \mathrm{uF}\end{array}$ & $\begin{array}{l}69 \\
64 \\
87 / 90\end{array}$ & $\begin{array}{l}77 / 79 \\
71 / 74\end{array}$ & $973-1035$ & Ohman and Snyder (1991) \\
\hline $\begin{array}{l}\text { S. spiralis } \\
\text { S. capitatum }\end{array}$ & Culture & $\begin{array}{l}2 \%, 5 \%, 10 \% \mathrm{~L} \\
2 \% \mathrm{bF}\end{array}$ & ND & $\begin{array}{l}74,66,59 \\
61,56,40\end{array}$ & $90-93(3)$ & Stoecker et al. (1994a) \\
\hline Halteria grandinella & Culture & $\begin{array}{l}1 \% \mathrm{~L} \\
2 \% \mathrm{uF}\end{array}$ & $\begin{array}{l}63 \\
90\end{array}$ & 70 & $300(3)$ & Wiackowski et al. (1994) \\
\hline Colpidium kleini & Culture & $\begin{array}{l}1 \% \mathrm{~L} \\
2 \% \mathrm{uF}\end{array}$ & $\begin{array}{l}80 \\
124\end{array}$ & 64 & $300(3)$ & \\
\hline Urotricha armata & Culture & $\begin{array}{l}1 \% \mathrm{~L} \\
2 \% \mathrm{uF}\end{array}$ & $\begin{array}{l}89 \\
95\end{array}$ & 94 & $210(3)$ & \\
\hline $\begin{array}{l}\text { Balanion sp., } \\
\text { Strombidium epidemum }\end{array}$ & $\begin{array}{l}\text { Plymouth } \\
\text { Sound }\end{array}$ & $\begin{array}{l}0.4 \% \mathrm{~L} \\
1 \% \mathrm{bF}\end{array}$ & ND & $\begin{array}{l}69 \\
42\end{array}$ & $\begin{array}{l}\max 50 \text { cells/taxon } \\
1 \text { sample (triplicate) }\end{array}$ & Leaky et al. (1994) \\
\hline $\begin{array}{l}\text { Laboea strobila, } \\
\text { Lohmaniella spp., } \\
\text { Tontonia spp., } \\
\text { Strombidium spp. }\end{array}$ & NE Atlantic & $\begin{array}{l}0.4 \% \mathrm{~L} \\
2 \% \mathrm{bF}\end{array}$ & ND & $75-119$ & $\begin{array}{l}8-240 \text { cells/taxon } \\
22 \text { samples }\end{array}$ & This study \\
\hline
\end{tabular}

Ratios expressed as percentages. ND: no data. $N(n)$ : number of cells counted (replicates per treatment) $\mathrm{L}=\mathrm{Lugol}$ 's, $\mathrm{F}=\mathrm{formalin}, \mathrm{uF} /$ $\mathrm{bF}=$ unbuffered/buffered formalin. 
also considered the initial short-term effects of fixation (maximum of 2 months) while some of our samples were counted up to 6 months after fixation; thus, the smaller difference between formalin and Lugol's biovolumes might indicate long-term shrinkage effect in formalin samples. In experiments conducted by Wiackowski et al. (1994), Halteria sp. continued to shrink after 2 months of storage in formalin but its volume did not change after 2 months of storage in Lugol's solution. According to Stoecker et al. (1994a) and Wiackowski et al. (1994), it seems that the effect of fixatives was not the same for all morphotypes and size-classes. Here, for example, cells with conical morphology (L. strobila, Strombidium spp. 3 and Tontonia spp.) showed the greatest shrinkage in Lugol's solution compared to formalin. Within species, this effect was different for the 4 cellvolume categories identified.

Estimates of mixotrophic ciliate abundance and biomass have been usually based on Lugol's counts of species with very distinctive gross morphologies Laboea sp. and Tontonia spp. (Dolan and Marrasé, 1995; Dolan et al., 1999; Quevedo and Anadón, 2000). However, our results in formalin counts showed that ciliates not distinguishable in Lugol's such as Strombidium spp. are important in terms of abundance and biomass. Similar results were reported for the oligotrophic Mediterranean Sea (Perez et al., 2000; Pitta and Giannakourou, 2000; Pitta et al., 2001). Thus, it seems that neither Lugol's nor formalin give accurate estimates of mixotrophs. An important observation in the present study is that abundance and biomass varied by the same factor in the two treatments (Fig. 2), indicating a non-selective loss of cells in formalin. Thus, if we consider the Lugol's to formalin ratio of abundance to be $2: 1$, then estimates for mixotrophic ciliates could be based on formalin counts multiplied by a factor of 2. Overall, these results indicate a severe underestimation of mixotrophic abundance and biomass in studies conducted up to now. Further investigation in samples rich in mixotrophs is necessary in order to establish a relationship between Lugol's and formalin fixed samples.

Finally, regarding tintinnids, it is suggested that cells leave their loricas when disturbed (Jörgensen, 1924) and there are indications that fixatives may also cause dissolution of agglomerated material and loricas themselves after long-term storage (Dale and Dahl,
1987). In many studies, only intact (full) loricas were counted and recorded (Sime-Ngando et al., 1990; Leaky et al., 1994). However, it is not clear whether empty loricas were dead or alive before fixation. If we assume all empty loricas were dead before fixation, this may lead to an underestimation of tintinnid abundance and biomass. Our results indicate that in contrast to aloricate ciliates, full or empty Tintinnus spp. loricas did not vary significantly between the two treatments. These results are similar to Leaky et al. (1994) who only counted intact cells of tintinnids in samples from Plymouth Sound.

Accurate quantification of ciliate abundances depends on a firm understanding of the relative strengths and weaknesses of both Lugol's and formalin solutions. Lugol's is generally preferred over formalin as it minimizes cell loss, although its big disadvantage is that it masks chlorophyll fluorescence, which is crucial in understanding a mixotrophic regime. This study established a $50 \%$ cell loss in formalin ciliate counts. With carbon budget estimates of primary production consumption by ciliates based on formalin counts (where chlorophyll can be distinguished), this could lead to a $100 \%$ error if a correction is not applied. Finally, as both fixatives have their advantages and disadvantages, we recommend duplicate counts using both fixatives in order to estimate mixotroph numbers as this is a more accurate quantitative procedure.

\section{Acknowledgements}

This work is a contribution to the POMME Programme. Financial support was provided by the CNRS-INSU, France. We thank the two anonymous reviewers for their suggestions to improve the manuscript.

\section{References}

Bernard, C., Rassoulzadegan, F., 1990. Bacteria or microflagellates as a major food source for marine ciliates: possible implications for the microzooplankton. Mar. Ecol., Prog. Ser. 64, $147-155$.

Bernard, C., Rassoulzadegan, F., 1993. The role of picoplankton (cyanobacteria and plastidic picoflagellates) in the diet of tintinnids. J. Plankton Res. 15, 361-373. 
Burkill, P.H., Edwards, E.S., John, A.W.G., Sleigh, M.A., 1993. Microzooplankton and their herbivorous activity in the northeastern Atlantic Ocean. Deep-Sea Res., Part 2, Top. Stud. Oceanogr. 40, 479-493.

Choi, J.W., Stoecker, D.K., 1989. Effects of fixation on cell volume of marine planktonic protozoa. Appl. Environ. Microbiol. 55, $1761-1765$.

Christaki, U., Jacquet, S., Dolan, J.R., Vaulot, D., Rassoulzadegan, F., 1999. Growth and grazing on Prochlorococcus and Synechococcus by two marine ciliates. Limnol. Oceanogr. 44, 52-61.

Dale, T., Dahl, E., 1987. Mass occurrence of planktonic oligotrichous ciliates in a bay in southern Norway. J. Plankton Res. 9, $871-879$.

Dolan, J.R., Marrasé, C., 1995. Planktonic ciliate distribution relative to a deep chlorophyll maximum: Catalan Sea, N.W. Mediterranean, June 1993. Deep-Sea Res., Part 1, Oceanogr. Res. Pap. 42, 1965-1987.

Dolan, J.R., Vidussi, F., Claustre, H., 1999. Planktonic ciliates in the Mediterranean Sea: longitudinal trends. Deep-Sea Res. 46, 2025-2039.

Dussart, B.M., 1965. Les différentes catégories de plancton. Hydrobiologia $26,72-74$.

Gifford, D.J., Caron, D.A., 2000. Sampling, preservation, enumeration and biomass of marine protozooplankton. In: Harris, R.P., Wiebe, P.H., Lenz, J., Skjoldal, H.R., Huntley, M. (Eds.), ICES Zooplankton Methodology Manual. Academic Press, Cornwall, pp. $193-221$.

Jonsson, P.R., 1987. Photosynthetic assimilation of inorganic carbon in marine oligotrichs ciliates (Ciliophora, Oligotrichina). Mar. Microb. Food Webs 2, 55-68.

Jörgensen, E., 1924. Mediterranean Tintinnidae. Report on the Danish Oceanographical Expeditions 1908-1910 to the Mediterranean and Adjacent Seas, vol. 2, J. 3 Andr. Fred. Høst and Son, Copenhagen. $110 \mathrm{pp}$.

Kofoid, C.A., Campbell, A.S., 1929. A conspectus of the marine and fresh-water Ciliata belonging to the suborder Tintinnoinea, with descriptions of new species principally from the Agassiz Expedition to the Eastern Tropical Pacific, 1904-1905. University of California Publications in Zoology, vol. 34. University of California Press, Berkeley, CA. 403 pp.

Laval-Peuto, M., Rassoulzadegan, F., 1988. Autofluorescence of marine planktonic Oligotrichina and other ciliates. Hydrobiologia $159,99-110$.

Leaky, R.J.G., Burkill, P.H., Sleigh, M.A., 1992. Planktonic ciliates in Southampton water: abundance, biomass, production, and role in pelagic carbon flow. Mar. Biol. 114, 67-83.

Leaky, R.J.K., Burkill, P.H., Sleigh, M.A., 1994. A comparison of fixatives for the estimation of abundance and biovolume of marine planktonic ciliate populations. J. Plankton Res. 16, $375-389$.

Levinsen, H., Nielsen, T.G., 2002. The trophic role of marine pelagic ciliates and heterotrophic dinoflagellates in arctic and temperate coastal ecosystems: a cross-latitude comparison. Limnol. Oceanogr. 47, 427-439.

Lynn, D.H., Montagnes, D.J.S., 1991. Global production of heterotrophic marine planktonic ciliates. In: Reid, P.C., Turley, C.M., Burkill, P.H. (Eds.), Protozoa and their Role in Marine
Processes. NATO Adv. Sci. Inst., vol. G25. Springer, Berlin, pp. $161-180$.

Maeda, M., 1986. An illustrated guide to the species of the families Halteriidae and Strobilidiidae (Oligotrichida, Ciliophora) free swimming protozoa common in aquatic environment. In: Asai, T., Kobayashi, K., Sakai, H., Nemoto, T., Kajihara, T. (Eds.), Bulletin of the Ocean Research Institute University of Tokyo, vol. 21. University of Tokyo. $67 \mathrm{pp}$.

Maeda, M., Carey, P.G., 1985. An illustrated guide to the species of the family Strombidiidae (Oligotrichida, Ciliophora), free swimming protozoa common in the aquatic environment. In: Asai, T., Kobayashi, K., Nemoto, T., Kajihara, T. (Eds.), Bulletin of the Ocean Research Institute University of Tokyo, vol. 19. University of Tokyo, Tokyo. 68 pp.

Montagnes, D.J.S., Lynn, D.H., 1991. Taxonomy of Choreotrichs, the major marine planktonic ciliates, with emphasis on the aloricate forms. Mar. Microb. Food Webs 5, 59-74.

Montagnes, D.J.S., Lynn, D.H., Roff, J.C., Taylor, W.D., 1988. The annual cycle of heterotrophic planktonic ciliates in the waters surrounding the Isles of Shoals, Gulf of Maine: an assessment of their trophic role. Mar. Biol. 99, 21-30.

Ohman, M.D., Snyder, R.A., 1991. Growth kinetics of the omnivorous oligotrich ciliate Strombidium sp. Limnol. Oceanogr. 36, 922-935.

Perez, M.T., Dolan, J.R., Vidussi, F., Fukai, E., 2000. Diel vertical distribution of planktonic ciliates within the surface layer of the NW Mediterranean (May 1995). Deep-Sea Res. 47, 479-503.

Pilling, E.D., Leaky, R.J.G., Burkill, P.H., 1992. Marine pelagic ciliates and their productivity during summer in Plymouth coastal waters. J. Mar. Biol. Assoc. U.K. 72, 265-268.

Pitta, P., Giannakourou, A., 2000. Planktonic ciliates in the oligotrophic Eastern Mediterranean Sea: vertical, spatial distribution and mixotrophy. Mar. Ecol., Prog. Ser. 194, 269-282.

Pitta, P., Giannakourou, A., Christaki, U., 2001. Planktonic ciliates in the oligotrophic Mediterranean Sea: longitudinal trends of standing stocks, distributions and analysis of food vacuole contents. Aquat. Microb. Ecol. 24, 297-311.

Putt, M., Stoecker, D.K., 1989. An experimentally determined carbon: volume ratio for marine "oligotrichous" ciliates from estuarine and coastal waters. Limnol. Oceanogr. 34, 1097-1103.

Quevedo, M., Anadón, R., 2000. Spring microzooplankton composition, biomass and potential grazing in the central Cantabrian coast (southern Bay of Biscay). Oceanol. Acta 23, 297-309.

Quevedo, M., Anadón, R., 2001. Protist control of phytoplankton growth in the subtropical north-east Atlantic. Mar. Ecol., Prog. Ser. 221, 29-38.

Revelante, N., Gilmartin, M., 1983. Microzooplankton distribution in the Northern Adriatic Sea with emphasis on the relative abundance of ciliated protozoans. Oceanol. Acta 6, 407-415.

Sherr, E.B., Sherr, B.F., 1993. Preservation and storage of samples for enumeration of heterotrophic protists. In: Kemp, P.F., Sherr, B.F., Sherr, E.B., Cole, J.J. (Eds.), Handbook of Methods in Aquatic Microbial Ecology. Lewis Publishers, Boca Raton, pp. $207-212$.

Sherr, E.B., Sherr, B.F., Fallon, R.D., Newell, S.Y., 1986. Small, aloricate ciliates as a major component of the marine heterotrophic nanoplankton. Limnol. Oceanogr. 31, 177-183. 
Sime-Ngando, T., Groliere, C.A., 1991. Effets quantitafs des fixateurs sur la conservation des ciliés planctoniques d'eau douce. Arch. Protistenkd. 140, 109-120.

Sime-Ngando, T., Hartmann, H.J., Groliere, C.A., 1990. Rapid quantification of Planktonic Ciliates: comparison of improved live counting with other methods. Appl. Environ. Microbiol. 56, 2234-2242.

Stoecker, D.K., 1991. Mixotrophy in marine planktonic ciliates: physiological and ecological aspects of plastid-retention by oligotrichs. In: Reid, P.C., Turley, C.M., Burkill, P.H. (Eds.), Protozoa and their Role in Marine Processes. NATO Adv. Sci. Inst., vol. G25. Springer, Berlin, pp. 161-179.

Stoecker, D.K., Michaels, A.E., Davis, L.H., 1987. Large proportion of marine planktonic ciliates found to contain functional chloroplasts. Nature 326, 790-792.

Stoecker, D.K., Taniguichi, A., Michaels, A.E., 1989. Abundance of autotrophic, mixotrophic and heterotrophic planktonic ciliates in Shelf and slope waters. Mar. Ecol., Prog. Ser. 50, 241-254.
Stoecker, D.K., Gifford, D.J., Putt, M., 1994a. Preservation of marine planktonic ciliates: loss and cell shrinkage during fixation. Mar. Ecol., Prog. Ser. 110, 293-299.

Stoecker, D.K., Sieracki, M.E., Verity, P.G., Michaels, A.E., Haugen, E., Burkill, P.H., Edwards, E.S., 1994b. Nanoplankton and protozoan microzooplankton during the JGOFS North Atlantic bloom experiment: 1989 and 1990. J. Mar. Biol. Assoc. U.K. 74, 427-443.

Suzuki, T., Ciotti, A.M., Odebrecht, C., 1991. The effect of formaldehyde and iodine as fixatives for phytoplankton and protozooplankton samples from the southern Brazilian coast. Neritica $6,65-71$.

Thouvenot, A., Richardot, M., Debroas, D., Devaux, J., 1999. Bacterivory of metazooplankton, ciliates and flagellates in a newly flooded reservoir. J. Plankton Res. 21, 1659-1679.

Wiackowski, K., Doniec, A., Fyda, J., 1994. An empirical study of the effect of fixation on ciliate cell volume. Mar. Microb. Food Webs 8, 59-69. 